\title{
Effect of the Self Etching Dentin Primers on the Bonding Efficacy of a Dentin Adhesive
}

\author{
Hisashi CHIGIRA, Toshie KOIKE, Tokuji HASEGAWA, Kazuo ITOH, \\ Sadao WAKUMOTO and Tohru HAYAKAWA* \\ Department of Operative Dentinstry, Showa University, School of Dentistry, 2-1-1- Kitasenzoku, \\ Ohta-ku Tokyo 145, Japan \\ *Department of Dental Materials, School of Dentistry at Matsudo, Nihon University, 870-1 Sakaecho, \\ Nishi-2 Matsudo, Chiba 271, Japan
}

Received on January 24,1989

Accepted on April 1, 1989

The efficacy of marketed and experimental self etching dentin primers which contained dicarboxylic acids or their esterified salts diluted in 35\% hydroxyethylmethacrylate (HEMA) solution were studied by measuring the wall-to-wall polymerization contraction of the light curing composite in the cylindrical dentin cavity and the tensile bond strength to the flat dentin surface. In both of the measurements, a marketed dentin bonding agent and resin monomer was applied after the treatment with experimental primers and a marketed primer, respectively. It was revealed that two experimental primers composed of the methacryloxyethyl-succinate or methacryloxyethyl-phthalate and HEMA, exhibited a remarkable effect on the bonding efficacy of a dentin adhesive employed in this study. A marketed primer which contained maleic acid and HEMA could not improve the bonding between the resin and dentin cavity wall although a significantly high bonding strength $(11.9 \pm 5.7 \mathrm{MPa})$ was obtained after 24 hours.

Key words : Dentin primer, Self etching, Contraction gap

\section{INTRODUCTION}

The adaptation of the composite resin restoration to the dentin cavity walls was determined by the efficacy of the dentin cleanser, dentin primer, dentin bonding agent and the composite resin employed in each step. The application of the dentin primer in the composite resin restoration was introduced by the invention of GLUMA ${ }^{1)}$ in 1984.

In order to simplify the clinical handling of this dentin bonding system by combining the steps of the dentin cleanser and the dentin primer, self etching dentin primer, which contained the acid or the acidic monomer, was recently reported ${ }^{2,3)}$.

Although the details of the bonding mechanism of the dentin primer were not clarified, the acid or the acidic monomer in the self etching primer may be effective on the treatment of the smear layer. The authors previously reported the effectiveness of the aqueous mixture of the glutaric acid, 4-META ${ }^{4)}$ or methacryloxyethyl succinate ${ }^{5,6)}$ and HEMA as self etching dentin primers. The purpose of the present study was to evaluate the effect of the primers which contained dicarboxylic acids or their esterified salts diluted in HEMA solution.

\section{MATERIALS AND METHODS}

1. Analysis of the marketed primer by HPLC 
The components of a marketed self etching dentin primer* were analyzed by means of high performance liquid chromatography $(\mathrm{HPLC})^{* *}$ with an ultraviolet (UV) spectrophotometric detector***. The chromatographic conditions are listed in Table 1.

2. Measurement of wall-to-wall polymerization contraction

The efficacy of the marketed primer and the experimental primers were evaluated by measuring the polymerization contraction of the light curing composite ${ }^{* * *}$ in the cylindrical dentin cavity.

Four dicarboxylic acids and their esterified salts studied, are listed in Fig 1. The experimental primers were prepared by mixing one of these materials with HEMA* in the proportion of 5 and $35 \%$ in distilled water.

The proximal enamel of an extracted human molar was eliminated on wet carborundum paper, No. 220, and the cylindrical cavity approximately $3 \mathrm{~mm}$ in diameter and $1.5 \mathrm{~mm}$ in depth was prepared in the exposed dentin. The cavity wall was then treated with one of the self etching dentin primers for $60 \mathrm{sec}$ and dried completely by a blast of compressed air. After the dentin bonding agent ${ }^{*}$ application, a visible light curing composite was slightly overfilled and the resin surface was covered with a plastic matrix on a glass plate under gentle pressure. In the group of the marketed primer, the resin monomer ${ }^{* *}$ was applied and polymerized in the cavity before application of the composite resin filling, according to the manufacturer's instruction. The composite was irradiated by use of a lamp unit *\# " for 40 $\mathrm{sec}$ and the specimens were stored in water at a room temperature of $24 \pm 1^{\circ} \mathrm{C}$ for $10 \mathrm{~min}$. The cavity margin was exposed on the wet carborundum paper and the alumina slurry on linen, and the width of the contraction gap was measured by the screw micrometer ${ }^{\circledR}$, mounted on the ocular lens of an optical microscope ${ }^{\circledR}$ at a magnification of 1024 . The maximum contraction was given in per cent to the cavity diameter in order to evaluate the degree of restraint for gap formation and to minimize the effect of the deviation of the cavity diameter ${ }^{7}$. Ten specimens were prepared for each primer.

3. Measurement of the tensile bond strength to dentin surface

In the group of methacryloxyethyl succinate, methacryloxyethyl phthalate, and the marketed dentin primer, the tensile bond strength was measured as follows : the flat dentin

Table 1 Chromatographic conditions.

\begin{tabular}{l|l}
\hline Column & ODS TM-800, Toyo Soda \\
Mobile phase & $60 \%$ Methanol- $40 \% \mathrm{H}_{2} \mathrm{O}$ \\
Flow rate & $0.4 \mathrm{ml} / \mathrm{min}$ \\
Detector & UV $235 \mathrm{~nm}$ \\
\hline
\end{tabular}

* Scotchprep; 3M, St. Paul MN, U.S. A.

** CCPD ; Toyo Soda, Kanagawa, Japan

*** UV-8000 ; Toyo Soda, Kanagawa, Japan

**** Silux ; 3M, St. Paul MN, U. S. A.

* HEMA ; E. Merck, Darmstadt, W. Germany

* Clearfil New Bond ; Kuraray Co., Osaka, Japan

* * Scotchbond 2; 3M, St. Paul MN, U. S. A.

* * * Quick Light; Morita, Kyoto, Japan

@ Model RZDO-DO ; Leitz, Wetzlar, W. Germany

(a) @ Metaloplan; Leitz, Wetzlar, W. Germany 
$\mathrm{HOOC}-\mathrm{CH}_{2} \mathrm{CH}_{2}-\mathrm{COOH}$

SA (Succinic Acid)<smiles>O=C(O)c1ccccc1C(=O)O</smiles>

PA (Phthalic Acid)<smiles>O=C(O)C=CC(=O)O</smiles>

MA (Maleic Acid)<smiles>O=C(O)C1CCC(C(=O)O)CC1</smiles>

CA (1,2-Cyclohexanedicarboxylic Anhydride)<smiles>C=C(C)C(=O)OCCOC(=O)CCC(=O)O</smiles>

MES (mono-(Methacryloxyethyl) Succinate)<smiles>C=C(C)C(=O)OCCOC(=O)c1ccccc1C(=O)O</smiles>

MEP (mono-(Methacryloxyethyl) Phthalate)<smiles>C=C(C)C(=O)OCCOC(=O)C=CC(=O)O</smiles>

MEM (mono-(Methacryloxyethyl) Maleate)<smiles>C=C(C)C(=O)OCCOC(=O)C1CCC(C(=O)O)CC1</smiles>

MEC (mono-(Methacryloxyethyl) Hexahydrophthalate)

Fig. 1 Acid or acidic monomer tested

surface of the human teeth, embedded in an epoxy resin ${ }^{\circledR} @$, was prepared on wet carborundum paper, No. 1,000. After treatment with one of the primers for $60 \mathrm{sec}$, a split teflon mold, inner diameter of $3.6 \mathrm{~mm}$, outer diameter of $20 \mathrm{~mm}$ and height of $8 \mathrm{~mm}$, was clamped onto the dentin surface. From the top window, a light activated composite was filled in the lower half of the mold, mediated with a dentin bonding agent and irradiated for $40 \mathrm{sec}$. Then a chemically activated composite $@^{\circledR @}$ was filled in the upper half of the mold and a round bar of No. 6 was inserted in the unpolymerized resin to make the grip of measurement. After storing the specimens in water for 24 hours, the tensile bond strength was measured by a universal testing machine ${ }^{\circ}$ with a cross head speed of $5 \mathrm{~mm} / \mathrm{min}$.

\footnotetext{
@ @ @ Epofix; Struers, Copenhagen, Denmark

@@@ @ P-10;3M, St. Paul MN, U.S. A.

- TCM-200 ; Minebea Co., Tokyo, Japan
} 
For the control, 35\% HEMA solution was applied on the dentin cavity wall prior to the application of the dentin bonding agent. In the group of the marketed primer, a resin monomer was applied prior to the composite filling.

Ten specimens were prepared for each primer.

\section{RESULTS}

1. The components of the marketed primer.

The HPL chromatogram is shown in Fig. 2. The peaks at $4.08 \mathrm{~min}$ and $6.65 \mathrm{~min}$ are identified as being derived from maleic acid and HEMA respectively. Although the unknown materials are shown in the chromatogram, it was revealed that Scotchprep contained HEMA and maleic acid.

2. The wall-to-wall polymerization contraction.

The maximum polymerization contraction measured, is presented in Table 2 .

In the group of the marketed primer, a considerably wide gap was observed in all specimens.

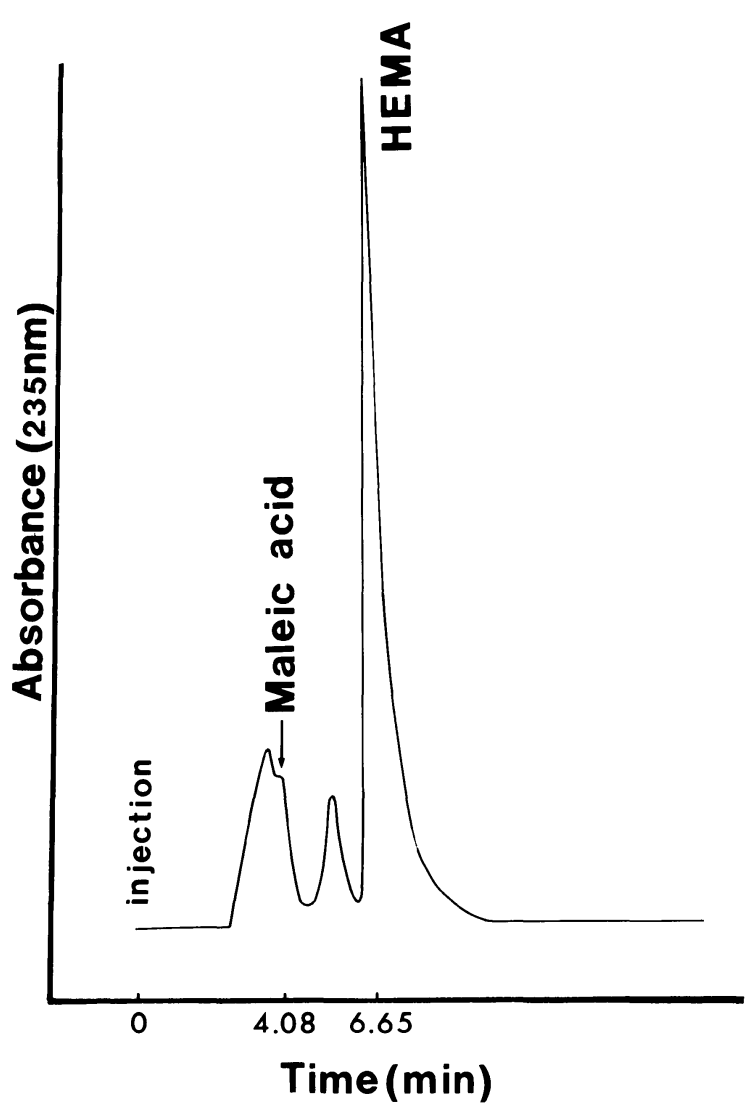

Fig. 2 HPL chromatogram 
Table 2 Effect of the experimental self etching dentin primer (acid or acidic monomer diluted in 35\% HEMA solution) and marketed self etching dentin primer in cylindrical dentin cavity.

\begin{tabular}{l|c|c}
\hline \multicolumn{1}{c|}{ Code } & WTW Contraction (\%)* & Gap Free Specimens \\
\hline CA & $0.076 \pm 0.066$ & 3 \\
MA & $0.186 \pm 0.058$ & 0 \\
PA & $0.054 \pm 0.055$ & 4 \\
SA & $0.045 \pm 0.054$ & 5 \\
MEC & $0.041 \pm 0.049$ & 5 \\
MEM & $0.094 \pm 0.082$ & 2 \\
MEP & $0.009 \pm 0.020$ & 8 \\
MES & $0.031 \pm 0.054$ & 7 \\
marketed primer** & $0.161 \pm 0.054$ & 0 \\
\hline
\end{tabular}

Clearfil New Bond was applied as the dentin bonding agent $\mathrm{N}=10$

*mean $\pm \mathrm{SD}$

***Scotchbond 2 was applied as the dentin bonding agent

Table 3 Tensile bond strength to human dentin of Clearfil New Bond pretreated by self ethching dentin primer.

\begin{tabular}{l|c}
\hline \multicolumn{1}{c|}{ Primer } & Tensile Bond Strength $(\mathrm{MPa})^{*}$ \\
\hline HEMA** $^{*}$ & $14.7 \pm 5.8$ \\
MES & $15.8 \pm 5.8$ \\
MEP & $15.8 \pm 6.4$ \\
marketed primer*** & $11.9 \pm 5.7$ \\
\hline \multicolumn{2}{c}{$\mathrm{N}=10$} \\
MES and MEP are diluted in 35\% HEMA solution \\
${ }^{*}$ mean \pm SD \\
${ }^{* * *}$ S5 HEMA solution for the control
\end{tabular}

In the group of the experimental primers which contained dicarboxylic acids, the maximum contraction decreased significantly, with one exception of maleic acid, and these values were further reduced by use of the esterified salts diluted in 35\% HEMA solution. A distinguished marginal adaptation was obtained with the methacryloxyethyl succinate and methacryloxyethyl phthalate, in which seven and eight specimens out of ten were gap free respectively.

3. Tensile bond strength to dentin surface.

Tensile bond strength to the human dentin surface after 24 hours is given in Table 3 . By the statistical analysis of t-test, no significant difference was observed between the three tested groups.

\section{DISCUSSSION}

It has been recognized that the primary requirement for the dentin bonding system is to prevent the contraction gap formation completely and to keep such tight adaptation for a long period. When high bonding strength is obtained during polymerization, the contraction 
of the composite resin is compensated by the flow of the composite from the free surface, resulting in reduced contraction in the cylindrical cavity. Therefore, it is considered meaningless to measure the tensile bond strength after 24 hours by using the dentin bonding system, which shows a relatively wide contraction gap, because resin material separates from the dentin cavity wall just after polymerization.

In this study, the tensile bond strength was measured using two bonding systems which showed significant effect in the contraction gap measurement and a marketed system for the control, although this system showed increased gap value. Other primers were omitted because of the above described reason.

It was previously claimed that the method or the material for the treatment of the smear layer on the ground dentin surface affected the marginal adaptation of the composite resin restoration. However, only a few dentin bonding systems available in the market have their own dentin cleanser in their kits, probably because the optimum technique is still unknown. Although some acid or mordants ${ }^{8-10)}$ were reported to be effective as dentin cleansers, Chiba $^{11)}$ reported that it was impossible to obtain the tight adaptation between resin materials and the dentin softened by the dentin cleanser. Therefore, the primary requirement for the dentin cleanser was not to decalcify the dentin beneath the smear layer. The difference between the efficiency of self etching dentin primers tested in this study might be explained by the degree of decalcification of the treated dentin which will be discussed in our next report ${ }^{12)}$.

The marketed primer didn't exhibit the bonding ability in this study and it was considered that some improvement should be required for this material. The 35\% HEMA solution containing two esterified dicarboxylic acids, methacryloxyethyl succinate or methacryloxyethyl phthalate, was considered to be effective for the self etching dentin primer and it might be considered that such effect was exhibited by the hydrophilic and the hydrophobic group of these monomers which were effective for dissolving the smear layer and the polymerization with resin monomer respectively, resulting in the excellent marginal adaptation. They were considered to be effective clinically if they had no pulp irritation. In order to establish the complete seal between the resin and the dentin cavity wall, more study is still required.

\section{CONCLUSION}

The efficacy of a marketed, and experimental self etching dentin primers which contained dicarboxylic acids or their esterified salts diluted in 35\% HEMA solution were studied by measuring the wall-to-wall polymerization contraction of Silux in the cylindrical dentin cavity and the tensile bond strength to the flat dentin surface. It was possible to conclude that two experimental primers composed of the methacryloxyethyl succinate or methacryloxyethyl phthalate and HEMA exhibited a remarkable effect on the dentin bonding of Clearfil New Bond. A marketed primer, Scotchprep, which contained maleic acid and HEMA could not improve the bonding between the resin and dentin cavity wall. 


\section{REFERENCES}

1) Munksgaard, E. C. and Asmussen, E. : Bond strength between dentin and restorative resins mediated by mixture of HEMA and glutaraldehyde. J Dent Res 63 : 1087-1089, 1984.

2) Hasegawa, T., Manabe, A., Itoh, K. and Wakumoto, S.: The effect of an experimental dentin primer composed of 35\% HEMA and glutaric acid, Japan J Conserv Dent 31: 422-427, 1988. (in Japanese)

3) Hasegawa, T., Manabe, A., Itoh K. and Wakumoto, S. : Investigation of self etching dentin primers, Dent Mater (submitted)

4) Takeyama, M., Kashibuchi, S., Nakabayashi, N. and Masuhara, E. : Studies on dental self-curing resins (17) - Adhesion of PMMA with bovine enamel or dental alloys, J. Japan Soc Dent Appar Mat 19(47) : 179-185, 1978. (in Japanese)

5) Fukushima, T.: Application of functional monomers for dental used (Part 6) - Synthesis of methacryloxy alkyl succinate and their adhesion to the tooth structure, $J$ J Dent Mater 38(4): 506-529, 1981. (in Japanese)

6) Fukushima, $\mathrm{T}$., Inoue, $\mathrm{Y}$. and Horibe, $\mathrm{T}$. : Synthesis of 2-methacryloxy ethyl hydrogen maleate and its bonding to tooth surfaces, $J J$ Dent Mat 7(4): 675-679, 1988.(in Japanese)

7) Munksgaard, E. C., Itoh, K., Asmussen, E. and Jorgensen, K. D. : Effect of combining dentin bonding agents, Scand J Dent Res 93(4): 377-380, 1985.

8) Fusayama, T., Nakamura, M., Kurosaki, N. and Iwaku, M. : Non-pressure adhesion restorative resin. $J$ Dent Res 58: 1364-1370, 1979.

9) Bowen, R. L. : Adhesive bonding of various materials to hard tooth tissue. XXII. The effect of cleanser, mordant, and poly SAC on adhesion between a composite resin and dentin, $J$ Dent Res 59(5) : 809-814, 1980.

10) Asmussen, E. and Bowen, R. L. : Effect of acidic pretreatment on adhesion to dentin mediated by Gluma, $J$ Dent Res 66(8): 1386-1388, 1987.

11) Chiba, M., Itoh, K. and Wakumoto, S. : Effect of dentin cleansers on bonding efficacy of dentin adhesive, Dent Mater J 8(1): 9-18, 1989.

12) Inagaki, A., Chigira, H., Itoh, K. and Wakumoto, S.: The effect of the self-etching primers on the dentin, Dent Mater (submitted) 
に比ベクリープ破壊に対し長期間抵抗した。混合型高銅 アマルガムは，破壊時のクリープ值が試験したアマルガ ム中でもっとも大きかった。これはこのアマルガムが 連続的な荷重に対し他のアマルガムに比べてより柔軟性 があるということを意味している。破壊時間はクリープ
速度の逆数にほぼ比例し，クリープ速度が減少すると破 壊時間は急激に増加した。この結果は，以前に報告され た一定期間内のクリープ值とアマルガム修復物の辺縁破 折との相関をクリープ破壊の面から説明し，裏付けてい る。

\section{象牙質処理剂がレジンの接着性に与える影響について}

千葉幹男，伊藤和雄，和久本貞雄

昭和大学歯学部第二歯科保存学教室

Dentin cleanserによって象牙質の受ける変化が接着 性にいかなる影響を及ぼすかについて，リン酸，グリシ ン含有ピルビン酸, EDTAによる歯面清掃を行なった後 の象牙質の物理的特性を計測し，これらとレジンとの接 着性の相関を検討した。その結果，レジンと象牙質との 接着性は, cleanserによって象牙質に与える変化のうち Micro Vickers Hardness の低下と最も高い相関を示し
た。すなわち, cleanserによって残存象牙質硬さが $85 \%$ 以上に保たれるEDTA-2Naによる処理が最も良好な 接着性を示した。このことから，良好な接着性を得るた めには smear layerのみを除去し，象牙質には全く影響 を及ぼさない cleanserが理想的な材料であると結論付 けられた。

\section{Self Etching Dentin Primer の効果}

千木良尚志*，小池斗誌江*，長谷川篤司*，伊藤和雄*，和久本貞夫*，早川 徹**

*昭和大学歯学部第二歯科保存学教室

**日本大学松戸歯学部歯科理工学教室

$35 \% \mathrm{HEMA}$ 水溶液に希釈されたジカルボン酸また は，そのエステル構造物を含む市販及び試作の Self Etching Dentin Primerの効果を象牙質円柱窩洞内での 可視光線重合型コンポジットレジンのコントラクション ギャップの計測と象牙質平面に対する引つ張り接着強さ によって評価した。

試作した primer はすべて市販のリン酸エステル系ボ ンディング材と，また市販品のセルフエッチングタイプ の primer は付属のレジンモノマーを併用し, 全ての窩 洞および被着面には，市販の光重合型コンポジットレジ
ンを垻塞または接着させた。

その結果, HEMA にメタクリロキシエチルコハク酸 または,メタクリロキシエチルフタル酸を溶解した 2 種 類の試作 primer が，今回用いられたボンディイグ材の 象牙質に対する接着性を著明に向上させた。また，マレ イン酸を含む市販の primer は, 24 時間後の引つ張り接 着強さが $11.9 \pm 5.7 \mathrm{MPa}$ と高い值を示したが，コンポ ジットレジンと象牙質窩壁との適合性を改善することは できなかった。

\section{水中浸漬下におけるコンポジットレジンの圧縮クリープ}

平野 進，平沢 忠

鶴胃大学歯学部歯科理工学教室

コンポジットレジンの圧縮クリープを 4 種の異なる応 力 (圧縮応力 $0 \sim 3.5 \mathrm{~kg} / \mathrm{mm}^{2}$ ) で水中浸漬下で 500 時間
にわたり行なった。得られた 4 種のクリープ曲線から, 一定時間経過したときの各クリープひずみと圧縮応力と 